\title{
Analisis Perubahan Penutupan Lahan dan Potensi Karbon di Taman Hutan Raya Pocut Meurah Intan, Aceh Indonesia
}

\author{
Rahmat Fadhli ${ }^{*}$, Sugianto ${ }^{2}$, Syakur ${ }^{2}$
}

${ }^{1}$ Masters Program in Land Resources Conservation, Postgraduate Program of Syiah Kuala University, Darussalam, Banda Aceh, Indonesia;

${ }^{2}$ Department of Soil Science and Land Resource Conservation, Faculty of Agriculture, Syiah Kuala University, Darussalam, Banda Aceh, Indonesia

\begin{abstract}
ABSTRAK
Perubahan penutupan lahan merupakan sektor penyumbang emisi gas rumah kaca terbesar, termasuk di dalamnya adalah pemanfaatan lahan. Analisis tutupan lahan menjadi bagian penting dalam menentukan jumlah potensi karbon yang tersedia. Penelitian bertujuan untuk menganalisis perubahan tutupan lahan dari tahun 2003 hingga 2018 dan menghitung potensi karbon di Taman Hutan Raya Pocut Meurah Intan dengan luas objek penelitian 6.215 ha. Penelitian dilaksanakan selama 5 (lima) bulan. Penelitian ini menggunakan metode stock difference, yaitu metode perhitungan luas tutupan lahan dan stok karbon pada dua titik waktu. Hasil penelitian menunjukkan bahwa perubahan luas tertinggi tahun 2018 seluas 263 ha dan terendah tahun 2009 seluas 108 ha. Lahan terbuka meningkat seluas 100 ha, pemukiman 81 ha, semak belukar 65 ha, pertanian lahan kering campur semak 32 ha. Sementara hutan lahan kering sekunder menurun 79 ha, hutan tanaman 76 ha, savanna 21 ha dan pertanian lahan kering 103 ha. Selama kurun waktu 15 tahun berdasarkan kelas penutupan lahan, cadangan karbon tertinggi pada tahun 2003 sebesar 656.053 ton, terendah tahun 2012 sebesar 620.992 ton. Laju serapan karbon tertinggi pada periode tahun 2015-2018 sebesar 94.615 ton $\mathrm{CO}_{2}$ dan terendah pada periode tahun 2009-2012 sebesar 1.981 ton $\mathrm{CO}_{2}$. Laju emisi tertinggi pada periode tahun 2003-2006 sebesar 79.559 ton $\mathrm{CO}_{2}$ dan terendah periode tahun 2006-2009 sebesar 9.069 ton $\mathrm{CO}_{2}$. Peningkatan serapan karbon diakibatkan oleh meningkatnya luas tutupan lahan pada hutan lahan kering sekunder dan adanya pemanfaatan lahan untuk pertanian lahan kering campur semak.
\end{abstract}

Kata kunci: Perubahan penutupan lahan, potensi karbon, $\mathrm{CO}_{2}$, pemanfaatan lahan, Taman Hutan Raya Pocut Meurah Intan

\begin{abstract}
Changes in land cover are the largest contributor to greenhouse gas emissions, including land use. Land cover analysis is an important part in determining the potential amount of carbon available. The study aims to analyze changes in land cover from 2003 to 2018 and calculating the carbon potential in the Pocut Meurah Intan Forest Park with a research object area of 6,215 ha. The research was conducted for 5 (five) months. This research uses the stock difference method, namely the method of calculating land cover area dan stok karbon pada dua titik waktu. The results showed that the highest area change in 2018 was 263 ha and the lowest was in 2009 at 108 ha. Open land increased by 100 ha, settlement 81 ha, scrub 65 ha, dry land agriculture mixed with shrubs 32 ha. Meanwhile, secondary dry land forest decreased by 79 ha, plantation forest 76 ha, savanna 21 ha and dry land agriculture 103 ha. Over a 15 year period based on land cover class, the highest carbon stock in 2003 was 656,053 tons, the lowest was in 2012 at 620,992 tons. The highest carbon absorption rate in the 2015-2018 period was 94,615 tons of $\mathrm{CO}_{2}$ and the lowest was in the 2009-2012 period of 1,981 tons of $\mathrm{CO}_{2}$. The highest emission rate in the 2003-2006 period was 79,559 tonnes of $\mathrm{CO}_{2}$ and the lowest for the 2006-2009 period was 9,069 tonnes of $\mathrm{CO}_{2}$. The increase in carbon sequestration is caused by the increase in land cover in secondary dryland forest and the use of land for mixed dry land agriculture.
\end{abstract}

Keywords: Changes in land cover, carbon potential, $\mathrm{CO}_{2}$, land use, Pocut Meurah Intan Forest Park

Citation: Fadhli, R., Sugianto. dan Syakur (2021). Analisis Perubahan Penutupan Lahan dan Potensi Karbon di Taman Hutan Raya Pocut Meurah Intan, Aceh Indonesia. Jurnal Ilmu Lingkungan, 19(2), 450-458, doi:10.14710/jil.19.2.450-458

\section{Pendahuluan}

Dalam konteks kerusakan hutan, meningkatnya laju kerusakan hutan di Indonesia telah menjadi salah satu penyumbang terjadinya perubahan iklim global atau pemanasan global. Berdasarkan data yang dirilis oleh FAO (2007) bahwa Indonesia di urutan ke-8 dari sepuluh negara dengan luas hutan alam terbesar di dunia, dengan laju kerusakan hutan di Indonesia telah mencapai 1,87 juta ha dalam kurun waktu 2000 -
2005. Hutan merupakan komponen penyerap $\mathrm{CO}_{2}$ yang cukup potensial. Pohon di dalam hutan mengabsorpsi $\mathrm{CO}_{2}$ selama proses fotosintesis dan menyimpannya sebagai materi organik dalam biomassa pohon. Brown (1997) mengemukakan bahwa hampir 50\% dari biomassa hutan tersusun atas karbon. Hutan yang semakin rusak, karena kejadian alam maupun pembalakan liar akan menambah jumlah GRK. Dalam hal fungsi hutan sebagai penghambat perubahan iklim yang dapat menyerap

*Penulis korespondensi: rdvdol@gmail.com 
$\mathrm{CO}_{2}$ yang diemisikan ke atmosfer menjadi menurun. Dengan demikian, peningkatan laju kerusakan hutan setidaknya akan mengurangi kemampuan hutan dalam menyimpan salah satu jenis GRK, yaitu karbon.

Provinsi Aceh memiliki Taman Hutan Raya Pocut Meurah Intan yang secara administratif berada di Kecamatan Lembah Seulawah Kabupaten Aceh Besar dan Kecamatan Simpang Beutong Kabupaten Pidie dengan luas 6.215 ha (SK Menhut No. 95/Kpts-II/2001 tanggal 15 Maret 2001). Taman Hutan Raya Pocut Meurah Intan merupakan kawasan pelestarian alam untuk tujuan koleksi tumbuhan dan satwa alami atau buatan, untuk kepentingan penelitian, menunjang budidaya, budaya, pariwisata, dan rekreasi. Djufri (2003) mengatakan bahwa Taman Hutan Raya sangat penting untuk mereduksi karbon di udara. Kemampuan dari Taman Hutan Raya dalam mereduksi karbon dapat ditelusuri dengan menduga cadangan karbon Taman Hutan Raya Pocut Meurah Intan. Situmorang et al., (2016) mengemukakan bahwa pendugaan cadangan karbon melalui pemanfaatan data penutupan lahan sangat membantu dalam mengestimasi cadangan karbon di dalam hutan mengingat luas hutan khususnya Provinsi Aceh sangat luas. Ismed et al., (2013) menyatakan bahwa besarnya cadangan karbon pada suatu tipe vegetasi dipengaruhi oleh tingginya jumlah pohon yang memiliki diameter (lingkar batang) yang besar, sehingga penebangan pohon untuk diambil potensi kayunya akan menurunkan jumlah karbon tersimpan pada suatu tipe vegetasi.

Penelitian ini bertujuan untuk menganalisis perubahan tutupan lahan dari tahun 2003 hingga 2018 dan menghitung potensi, emisi dan serapan karbon berdasarkan kelas penutupan lahan di Taman Hutan Raya Pocut Meurah Intan.

\section{Metode Penelitian}

\subsection{Lokasi dan Waktu Penelitian}

Penelitian ini dilaksanakan di Taman Hutan Raya (Tahura) Pocut Meurah Intan Provinsi Aceh Pengumpulan data, ground check dan pendataan lapangan dilakukan dari bulan Desember 2019 sampai Mei 2020. Peta lokasi penelitian diperlihatkan pada Gambar 1.

\subsection{Alat dan Bahan}

Alat dan bahan yang digunakan adalah Landsat- 5 , Landsat-7 dan Landsat-8 OLI Path 131 Row 56 liputan sejak tahun 2003 sampai dengan 2018, Peta Penutupan Lahan Taman Hutan Raya, Peta kawasan, Peta administrasi digunakan selama pengumpulan data dan Informasi tutupan lahan. Alat yang digunakan software ArcGis 10.1, MS Office, computer, Global Positioning System (GPS) untuk pemetaan, analisis spasial dan pengolahan data.

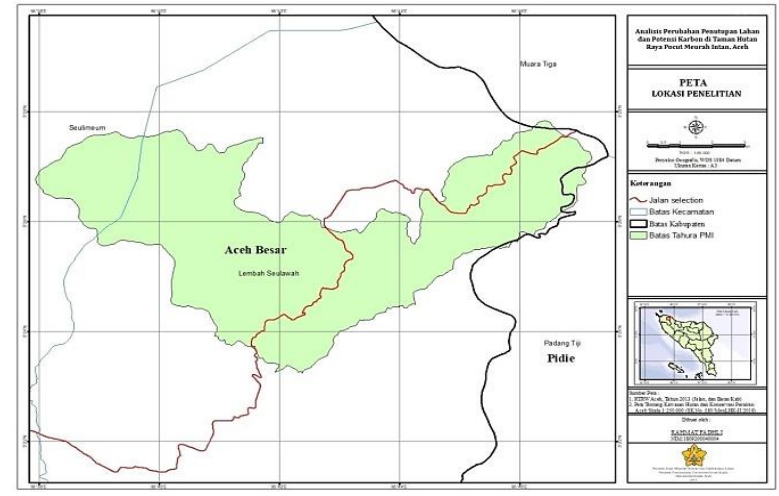

Gambar 1. Peta Lokasi Penelitian

\subsection{Metode Pengumpulan dan Analisis Data}

Penelitian ini bersifat deskriptif, menggunakan data primer dan sekunder. Data primer berupa data spasial, data lapangan. Data sekunder sebagai data penunjang meliputi data sosial dan kependudukan yang berdekatan dengan Taman Hutan Raya Pocut Meurah Intan diperoleh dari instansi pemerintah. Pengumpulan data spasial meliputi data administrasi, peta jenis tanah, peta kelerengan, Rupa Bumi Indonesia skala 1: 50.000, jaringan sungai dan data spasial penutupan lahan kurun waktu 15 tahun dari tahun 2003 - 2018 (periode per 3 tahun) hasil interpretasi citra satelit yang berpedoman pada kementerian lingkungan hidup dan kehutanan, lalu divalidasi kembali dengan skala di wilayah penelitian.

Analisis perubahan penutupan lahan di Taman Hutan Raya Pocut Meurah Intan menggunakan metode pengklasifikasian yang merupakan ekstraksi perubahan informasi dari-ke (from-to) berupa informasi tematik atau kategori yang didapatkan dari overlay data penutupan lahan dari tahun ke tahun antara peta penutupan lahan tahun 2003, 2006, 2009, 2012, 2015 dan 2018 (periode per 3 tahun) dengan menggunakan software Arc.Gis 10.4 yang akan menghasilkan matriks transformasi perubahan penutupan lahan (Jensen, 1996). Interpretasi peta Citra Landsat-7 dan Landsat-8 OLI Path 131 Row 56 liputan sejak tahun 2003 sampai dengan 2018 kurun waktu 15 tahun (periode per 3 tahun) dilakukan untuk mengetahui tutupan lahan eksisting dengan melakukan pengkelasan sesuai SNI 7645 (BSN, 2010). Analisis spasial dilakukan dengan tumpang susun (overlay) kelas penutupan lahan pada waktu pengamatan awal $\left(\mathrm{T}_{0}\right)$ dengan kelas penutupan lahan pada waktu berikutnya $\left(\mathrm{T}_{1}\right)$, melakukan analisis objek yang tidak berubah (pada $\mathrm{T}_{0}$ dan $\mathrm{T}_{1}$ ) dan yang berubah (objek pada $\mathrm{T}_{0}$ dan $\mathrm{T}_{1}$ tidak sama), menghitung luasan pada setiap objek yang mengalami perubahan dan yang tidak mengalami perubahan (BSN, 2014).

Analisis tabular (BSN, 2014) dilakukan dengan menghitung luasan pada tiap kelas penutupan lahan pada dua waktu pengamatan, menghitung luas perubahan tutupan lahan (periode per 3 tahun) menggunakan rumus sebagai berikut: 


$$
\mathrm{PTH}=\left(\mathrm{A}_{1}-\mathrm{A}_{0}\right) /\left(\mathrm{T}_{1}-\mathrm{T}_{0}\right)
$$

Keterangan : PTH adalah perubahan tutupan hutan/lahan per tahun pada periode tertentu (ha/tahun), Ao adalah luas area pada waktu pengamatan awal (ha), $\mathrm{A}_{1}$ merupakan luas area pada waktu pengamatan akhir (ha), $\mathrm{T}_{0}=$ tahun pengamatan awal, $\mathrm{T}_{1}=$ tahun pengamatan akhir.

Analisis potensi karbon berdasarkan kelas penutupan lahan dilakukan melalui analisis spasial berbasis SIG dengan menggunakan data aktivitas dan data cadangan karbon untuk tiap kelas penutupan lahan (Tosiani et al., 2017). Kelas penutupan lahan yang dipakai dalam penelitian ini menggunakan kelas penutupan lahan model SNI8033 BSN (2014). Penghitungan cadangan karbon dilakukan dengan menghitung luas dari masing-masing kelas penutupan lahan di Taman Hutan Raya Pocut Meurah Intan kurun waktu 15 tahun sejak tahun 2003 - 2018 (periode per 3 tahun) yang disebut sebagai data aktivitas tahunan, Dalam penelitian ini digunakan data cadangan karbon untuk tiap kelas penutupan lahan di atas permukaan (above ground biomass) pada 8 kelas penutupan lahan dari hasil analisis data- Inventarisasi Hutan Nasional dan berbagai literatur.

\section{Hasil dan Pembahasan}

\subsection{Perubahan Penutupan Lahan Taman Hutan Raya Pocut Meurah Intan}

Penelitian ini mengklasifikasikan penutupan lahan Taman Hutan Raya Pocut Meurah Intan menjadi 8 kelas tutupan lahan, 2 kelas tutupan hutan dan 6 kelas tutupan non hutan dengan luas 6.215 ha. Penentuan kelas penutupan lahan didasarkan pada penafsiran citra landsat terhadap penampilan lapangan atas batas-batas yang jelas dan disesuaikan dengan kondisi lapangan di lokasi penelitian. Penentuan kelas tutupan lahan yang dilakukan meliputi; hutan lahan kering sekunder, hutan tanaman, semak belukar, savana/rumput, pertanian lahan kering, pertanian lahan kering campur semak, pemukiman dan tanah terbuka.

Berdasarkan hasil klasifikasi digital dengan metode klasifikasi terbimbing terhadap citra landsat tahun 2003, 2006, 2009, 2012, 2015 dan 2018, Taman Hutan Raya Pocut Meurah Intan mengalami perubahan tutupan lahan pada semua kelas tutupan lahannya. Selama kurun waktu 15 tahun sejak tahun 2003 hingga 2018 telah terjadi perubahan luas baik peningkatan maupun penurunan luas wilayah tutupan lahan yang terdapat dalam kawasan Taman Hutan Raya Pocut Meurah Intan. Perubahan tersebut dapat dilihat pada Tabel 1 dan Tabel 2 .

Selanjutnya dikalikan dengan data cadangan karbon per penutupan lahan. Total cadangan karbon dibuat dengan rumus persamaan (Tosiani, 2015) yaitu:

Cadangan karbon total pertahun $=\mathrm{A}($ ton $/ \mathrm{ha}) \times \mathrm{B}(\mathrm{ha})$
Keterangan : $\mathrm{A}=$ cadangan karbon per tutupan lahan (ton/ha), B= data aktivitas tahunan/luas penutupan lahan (ha).

Perubahan stok karbon berdasarkan kelas penutupan lahan secara sederhana didapat melalui inventarisasi stok karbon secara berulang atau diistilahkan "stock difference method" (IPCC, 2006; $\mathrm{KLH}, 2012$ ) dilakukan dengan cara menghitung luas tutupan lahan masing-masing kelas penutupan lahan, menghitung rata-rata stok karbon pada masingmasing tutupan lahan dan menghitung total stok karbon pada waktu 1, waktu 2 dan seterusnya,selanjutnya menghitung selisih antara stok karbon waktu 1 dan waktu 2 untuk mendapatkan nilai perubahan stok karbon. Penghitungan perubahan cadangan karbon menggunakan persamaan :

$$
\Delta \mathrm{C}=\left(\mathrm{Ct}_{2}-\mathrm{Ct}_{1}\right) /\left(\mathrm{t}_{2}-\mathrm{t}_{1}\right)
$$

Keterangan : $\Delta \mathrm{C}=$ perubahan cadangan karbon pertahun pada setiap tampungan karbon (ton $\mathrm{C} /$ tahun), $\mathrm{Ct}_{1}=$ cadangan karbon pada tampungan karbon pada tahun $\mathrm{t}_{-1}$ (ton $\mathrm{C}$ ), $\mathrm{Ct}_{2}=$ cadangan karbon pada tampungan karbon pada tahun $\mathrm{t}-2$ (ton $\mathrm{C}$ ), $\mathrm{t}_{1}=$ tahun pengamatan awal, $\mathrm{t}_{2}=$ tahun pengamatan akhir. Tosiani (2015) menyatakan bahwa konversi dari karbon ke $\mathrm{CO}_{2}$ dengan- menggunakanhasil perkalian cadangan karbon (C) dengan faktor 3,67 (44/12).

Berdasarkan Tabel 1 memperlihatkan setiap tahunnya selama 15 tahun sejak tahun 2003 hingga 2018 terjadi perubahan tutupan lahan baik penambahan maupun penurunan luas. Perubahan luas tertinggi terdapat pada tahun 2018 seluas 263 ha dan terendah pada tahun 2009 seluas 108 ha.

Tahun 2006 terjadi perubahan luas penutupan lahan seluas 128 ha meliputi; penambahan luas pada semak belukar seluas 128 ha dan penurunan luas pada hutan lahan kering sekunder 128 ha. Tahun 2009 terjadi perubahan luas penutupan lahan seluas 108 ha meliputi; penambahan luas pada hutan lahan kering sekunder seluas 34 ha, lahan terbuka 73,94 ha dan penurunan luas pada semak belukar 80 ha, savanna/rumput 28 ha. Tahun 2012 terjadi perubahan luas penutupan lahan seluas 145 ha meliputi; penambahan luas pada pertanian lahan kering 24 ha, lahan terbuka 121 ha dan penurunan luas pada hutan lahan kering sekunder 119 ha, hutan tanaman 11 ha, semak belukar 3 ha dan savanna/rumput 13 ha. Tahun 2015 mengalami perubahan luas penutupan lahan seluas 190 ha meliputi; penambahan luas pada semak belukar 128 ha, savanna/rumput 20 ha, pemukiman 42 ha dan penurunan luas pada hutan lahan kering sekunder 11 ha, hutan tanaman 14 ha, pertanian lahan kering 24 ha dan lahan terbuka 141 ha. Tahun 2018 terjadi perubahan luas penutupan lahan seluas $263 \mathrm{ha}$ meliputi; penambahan luas pada Hutan lahan kering sekunder 145 ha, pertanian lahan kering campur semak 32 ha, pemukiman 39 ha, lahan terbuka 46 ha dan penurunan luas pada hutan tanaman seluas 50 ha, semak belukar 109 ha, savanna/rumput seluas 1 ha dan pertanian lahan kering 102 ha. 
Fadhli, R., Sugianto. dan Syakur (2021). Analisis Perubahan Penutupan Lahan dan Potensi Karbon di Taman Hutan Raya Pocut Meurah Intan, Aceh Indonesia. Jurnal IImu Lingkungan, 19(2), 450-458, doi:10.14710/jil.19.2.450-458

Tabel 1. Luas Penutupan Lahan Tahura Pocut Meurah Intan tahun $2003-2018$

\begin{tabular}{|c|c|c|c|c|c|c|c|}
\hline \multirow[t]{2}{*}{ No } & \multirow{2}{*}{$\begin{array}{c}\text { Kelas Penutupan } \\
\text { Lahan }\end{array}$} & Luas (ha) & Luas (ha) & Luas (ha) & Luas (ha) & Luas (ha) & Luas (ha) \\
\hline & & 2003 & 2006 & $200 !$ & 2012 & 2015 & 2018 \\
\hline 1 & $\begin{array}{l}\text { Hutan lahan kerin£ } \\
\text { sekunder }\end{array}$ & 3.391 & 3.263 & 3.297 & 3.179 & 3.168 & 3.313 \\
\hline 2 & Hutan tanaman & 118 & 118 & 118 & 106 & 93 & 42 \\
\hline 3 & Semak belukar & 2.307 & 2.435 & 2.355 & 2.353 & 2.481 & 2.372 \\
\hline 4 & Savanna/ rumput & 287 & 287 & 259 & 246 & 267 & 266 \\
\hline 5 & $\begin{array}{l}\text { Pertanian lahar } \\
\text { kering }\end{array}$ & 103 & 103 & 103 & 127 & 102 & 0 \\
\hline 6 & $\begin{array}{lr}\begin{array}{l}\text { Pertanian } \\
\text { kering } \\
\text { semak }\end{array} & \begin{array}{l}\text { lahar } \\
\text { campu }\end{array} \\
\end{array}$ & 3 & 3 & 3 & 3 & 3 & 35 \\
\hline 7 & Pemukiman & 0 & 0 & 0 & 0 & 42 & 81 \\
\hline 8 & Lahan terbuka & 6 & 6 & 80 & 202 & 61 & 107 \\
\hline & Luas (ha) & 6.215 & 6.215 & 6.215 & 6.215 & 6.215 & 6.215 \\
\hline
\end{tabular}

Sumber : Hasil pengolahan dan analisis data (2020)

Tabel 2. Matriks Perubahan Penutupan Lahan Tahura Pocut Meurah Intan tahun 2003 - 2018

\begin{tabular}{|c|c|c|c|c|c|c|c|}
\hline \multirow[t]{2}{*}{ No } & \multirow{2}{*}{$\begin{array}{c}\text { Kelas Penutupan } \\
\text { Lahan }\end{array}$} & \multicolumn{6}{|c|}{ Perubahan (ha) } \\
\hline & & 2003 & 2006 & 2009 & 2012 & 2015 & 2018 \\
\hline 1 & $\begin{array}{l}\text { Hutan lahan } \\
\text { kering sekunder }\end{array}$ & 3.391 & (128) & 34 & (119) & (11) & 145 \\
\hline 2 & Hutan Tanaman & 118 & 0 & 0 & (11) & (14) & $(50)$ \\
\hline 3 & Semak belukar & 2.307 & 128 & $(80)$ & (3) & 128 & (109) \\
\hline 4 & $\begin{array}{l}\text { Savanna/ } \\
\text { rumput }\end{array}$ & 287 & 0 & (28) & (13) & 20 & (1) \\
\hline 5 & $\begin{array}{l}\text { Pertanian Lahan } \\
\text { Kering }\end{array}$ & 103 & 0 & 0 & 24 & (24) & (102) \\
\hline 6 & $\begin{array}{l}\text { Pertanian lahan } \\
\text { kering campur } \\
\text { Semak }\end{array}$ & 3 & 0 & 0 & 0 & 0 & 32 \\
\hline 7 & Pemukiman & 0 & 0 & 0 & 0 & 42 & 39 \\
\hline 8 & Lahan Terbuka & 6 & 0 & 73,94 & 121 & (141) & 46 \\
\hline \multicolumn{2}{|c|}{ Total Luas bertambah (ha) } & & 128 & 108 & 145 & 190 & 263 \\
\hline \multicolumn{2}{|c|}{ Total Luas berkurang (ha) } & & $(128)$ & $(108)$ & $(145)$ & $(190)$ & $(263)$ \\
\hline
\end{tabular}

Sumber : Hasil pengolahan dan analisis data (2020)

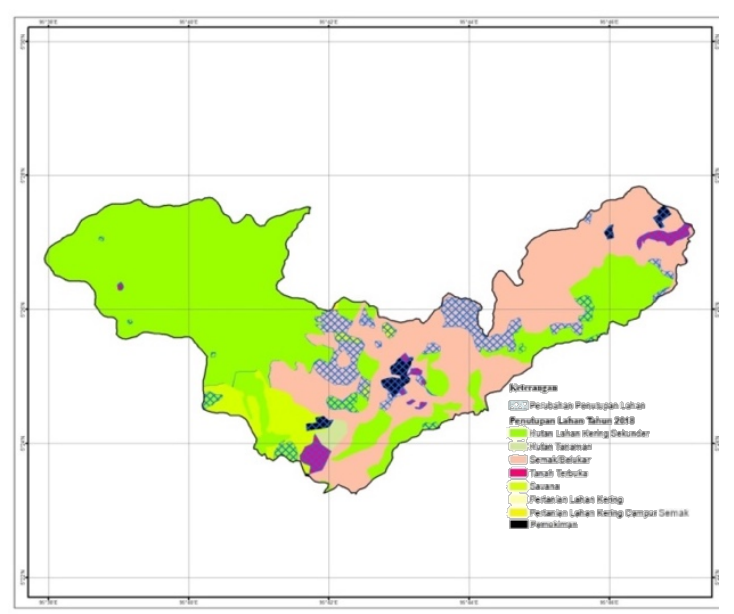

Gambar 2. Peta perubahan penutupan lahan Taman Hutan

Raya Pocut Meurah Intan dari tahun 2003 hingga 2018.

(Sumber: Hasil pengolahan dan analisis data, 2020) 
Tabel 3. Perubahan Penutupan Lahan Tahura Pocut Meurah Intan kurun waktu 15 tahun dari tahun 2003-2018

\begin{tabular}{clccccc}
\hline No & $\begin{array}{c}\text { Kelas } \\
\text { Penutupa } \\
\text { n Lahan }\end{array}$ & $\begin{array}{c}\text { Luas } \\
\text { (ha) }\end{array}$ & $\begin{array}{c}\text { Luas } \\
\text { (ha) }\end{array}$ & $\begin{array}{c}\text { Perubahan } \\
\text { (ha) }\end{array}$ & $\begin{array}{c}\text { Persentase } \\
\text { perubahan } \\
\text { terhadap kelas PL }\end{array}$ & $\begin{array}{c}\text { Persentase } \\
\text { Perahan terhadap } \\
\text { luas Tahura }\end{array}$ \\
\cline { 2 - 7 } 1 & 2003 & 2018 & & $(\%)$ & $(\%)$ \\
\hline & $\begin{array}{l}\text { Hutan lahar } \\
\text { kering } \\
\text { sekunder }\end{array}$ & 3.391 & 3.313 & $(79)$ & $(2,33)$ & $(1,27)$ \\
\hline 2 & $\begin{array}{l}\text { Hutan } \\
\text { tanaman }\end{array}$ & 118 & 42 & $(76)$ & $-(64)$ & $1,22)$ \\
\hline 3 & $\begin{array}{l}\text { Semak } \\
\text { belukar }\end{array}$ & 2.307 & 2.372 & 65 & 2,82 & 1,05 \\
\hline 4 & $\begin{array}{l}\text { Savanna/ } \\
\text { rumput }\end{array}$ & 287 & 266 & $(21)$ & $-7 \%$ & $(0,34)$ \\
\hline 5 & $\begin{array}{l}\text { Pertanian } \\
\text { lahan kering }\end{array}$ & 103 & 0 & $(103)$ & $(100)$ & 0,52 \\
\hline 6 & $\begin{array}{l}\text { Pertanian lah } \\
\text { kering camp } \\
\text { semak }\end{array}$ & 3 & 35 & 32 & 116,2 & $1,65)$ \\
\hline 7 & Pemukiman & 0 & 81 & 81 & 100 & 1,61 \\
\hline 8 & Lahan terbuk & 6 & 107 & 100 & 158,4 & \\
\hline & Luas (ha) & 6.215 & 6.215 & & & \\
\hline
\end{tabular}

Sumber : Hasil pengolahan dan analisis data (2020)

Secara keseluruhan perubahan penutupan lahan di Taman Hutan Raya Pocut Meurah Intan selama kurun waktu 15 tahun dari tahun 2003 hingga 2018 diperoleh bahwa telah terjadi perubahan luas pada semua kelas penutupan lahan seperti tertera pada Tabel 3.

Tabel 3 dijelaskan bahwa selama kurun waktu 15 tahun dari tahun 2003 hingga 2018 telah terjadi perubahan luas pada semua kelas penutupan lahan Taman Hutan Raya Pocut Meurah Intan.

Perbandingan penutupan lahan dari tahun 2003 hingga 2018 diperoleh penurunan luas penutupan lahan kelas hutan lahan kering sekunder seluas 79 ha atau 2,33\%, hutan tanaman 76 ha atau $64 \%$, savanna/rumput 21 ha atau $7,33 \%$, kelas pertanian lahan kering menjadi hilang 103 ha atau 100\%. Sementara penambahan luas penutupan lahan selama kurun waktu 15 tahun dari tahun 2003 hingga 2018 terjadi di kelas semak 65 ha atau 2,82\%, pertanian lahan kering campur semak 32 ha atau $116,2 \%$, pemukiman 81 hha atau $100 \%$ dan lahan terbuka 100 ha atau $158,5 \%$.

Perubahan luas penutupan lahan Taman Hutan Raya Pocut Meurah Intan yang mendominasi adalah hilangnya kelas pertanian lahan kering seluas 103 ha atau $100 \%$, penambahan kelas pemukiman meningkat 81 ha atau $100 \%$, meningkatnya luas pertanian lahan kering campur semak 32 ha atau $116 \%$, lahan terbuka 100 ha atau $158 \%$ dan bertambahnya luas semak belukar 65 ha.

Perubahan luas penutupan lahan secara umum mengalami penurunan. Penurunan tersebut terjadi akibat meningkatnya pemanfaatan lahan untuk pemukiman dan perluasan lahan untuk pertanian lahan kering campur semak. Pada umumnya di negara berkembang, lahan dikonversi menjadi lahan pertanian untuk keperluan peningkatan kebutuhan pangan (Campos, et al., 2005). Tren perubahan lahan
Taman Hutan Raya Pocut Meurah Intan tahun 20032018 dapat dilihat dalam Gambar 2 dan Gambar 3. Melihat dinamika perubahan penutupan lahan yang terjadi selama kurun waktu 15 tahun pada kelas pemukiman, pertanian lahan kering campur semak, lahan terbuka dan semak belukar mengindikasikan bahwa tingginya aktivitas manusia dalam kegiatan penebangan pohon, pembukaan lahan untuk bercocok tanam serta adanya bangunan dalam kawasan Taman Hutan Raya Pocut Meurah Intan. Perubahan penutupan lahan semak belukar menjadi lahan terbuka dimungkinkan karena adanya aktivitas bercocok tanam yang sudah ditinggalkan oleh masyarakat. Dari sisi lain juga adanya peningkatan luas penutupan hutan lahan kering sekunder akibat terjadinya suksesi alami sehingga tutupan lahan meningkat. Tren perubahan penutupan lahan Tahura dapat dilihat pada Gambar 4.

Akbar et al.,(2018) menjelaskan bahwa ketidakselarasan penggunaan lahan umumnya didominasi oleh penggunaan lahan yang diperuntukkan untuk kawasan Taman hutan raya Pocut Meurah Intan namun telah berubah menjadi kawasan pertanian dan permukiman. Kebutuhan penduduk yang meningkat dapat mendorong keinginan masyarakat untuk memanfaatkan lahan termasuk juga memanfaatkan lahan di kawasan. (Tren perubahan penutupan lahan dapat dilihat pada Gambar 4.

Hasil analisis Tahura PMI (2013) dalam Akbar et al.,(2018) menunjukkan pengurangan area hutan per tahun rata-rata seluas 238,71 ha. Hasil penelitian Samsul et al.,(2018), menyatakan bahwa tingginya aktivitas masyarakat di wilayah sekitar kawasan Taman Hutan Raya Pocut Meurah Intan menyebabkan perubahan fisik, seperti kegiatan masyarakat membuka lahan dengan cara menebang hutan, alih fungsi lahan hutan menjadi lahan perkebunan 
Fadhli, R., Sugianto. dan Syakur (2021). Analisis Perubahan Penutupan Lahan dan Potensi Karbon di Taman Hutan Raya Pocut Meurah Intan, Aceh Indonesia. Jurnal IImu Lingkungan, 19(2), 450-458, doi:10.14710/jil.19.2.450-458

monokultur dan pembakaran hutan. Ismed et al.,(2013) menambahkan bahwa keterbatasan lahan untuk memenuhi kebutuhan manusia, menyebabkan terjadinya perubahan atau alih fungsi penggunaan lahan seperti konversi hutan menjadi berbagai jenis penggunaan lahan untuk pertanian, perkebunan, hutan tanaman, pemukiman serta illegal logging.

\subsection{Potensi cadangan karbon berdasarkan kelas penutupan lahan}

Potensi cadangan karbon yang digunakan dalam penelitian adalah karbon di atas permukaan tanah. Untuk masing-masing kelas penutupan lahan yang dipakai dalam penelitian ini menggunakan kelas penutupan lahan model SNI8033 BSN (2014).

Sedangkan nilai cadangan karbon per hektar yang digunakan menggunakan referensi cadangan karbon yang bersumber pada Tosiani (2015), Direktorat IPSDH dan Badan Litbang Kehutanan Kementerian Kehutanan (2014) berdasarkan hasil pengukuran (NFI 1996-2013) dan Juknis PEP RAD GRK, 2013.

Penghitungan potensi cadangan karbon berdasarkan penutupan lahan diperlukan untuk mendapatkan informasi mengenai kemampuan luas penutupan lahan menyerap karbon.
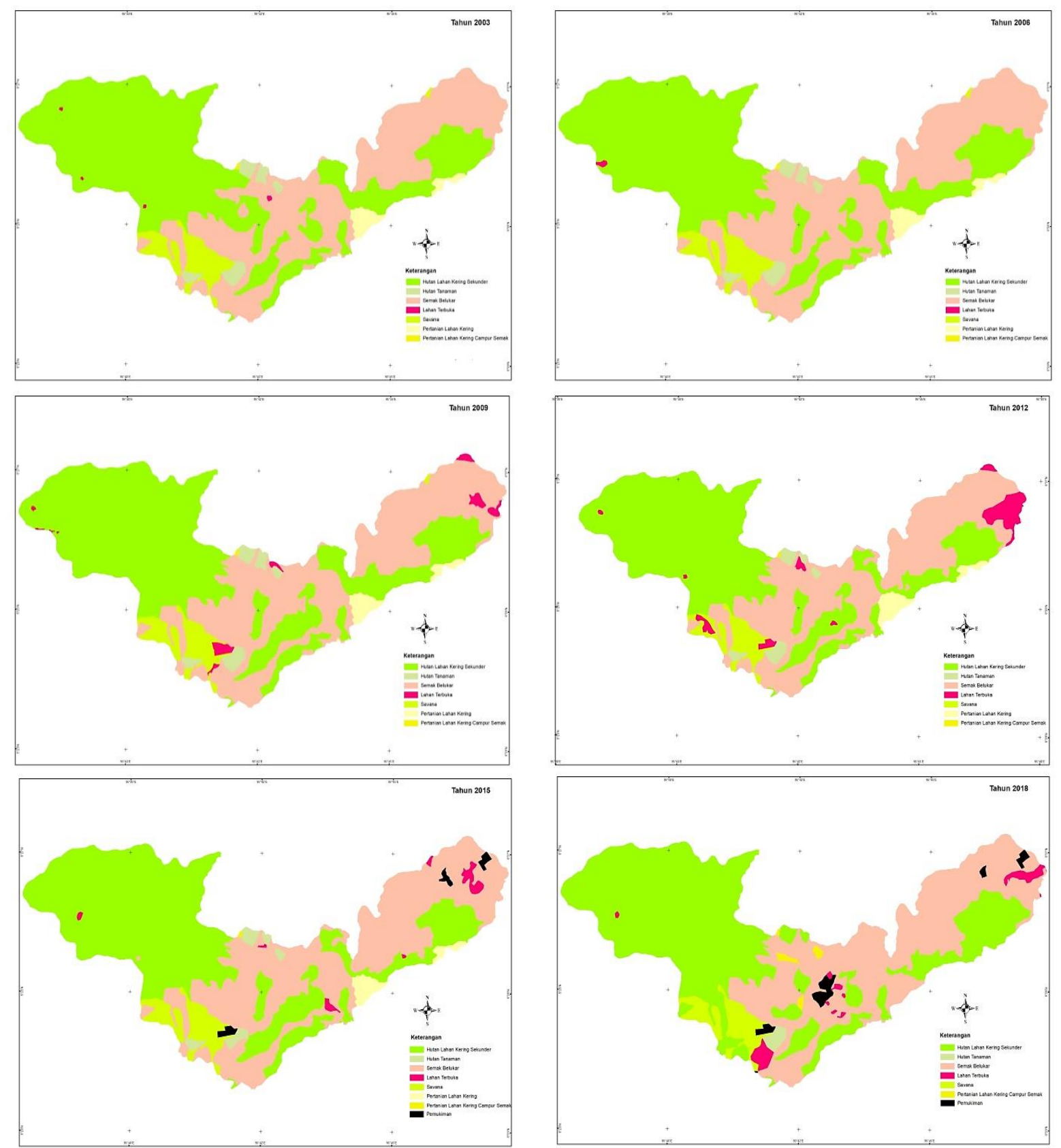

Gambar 3. Peta penutupan lahan Tahura Pocut Meurah Intan tahun 2003-2018 (periode per 3 tahun) 
Berdasarkan hasil analisis penutupan lahan Taman Hutan Raya Pocut Meurah Intan selama kurun waktu 15 tahun dari tahun 2003 hingga 2018, potensi cadangan karbon setiap tahun bervariasi dari 620.992-656.053 ton seperti tertera pada Tabel 4 .

Tabel 4 menjelaskan Tahura Pocut Meurah Intan memiliki potensi cadangan karbon tertinggi pada tahun 2003 sebesar 656.053 ton dan potensi cadangan karbon terendah pada tahun 2012 sebesar 620.992 ton. Hal ini menunjukkan bahwa selama kurun waktu 15 tahun mengalami tren penurunan potensi karbon sejak tahun 2003 hingga 2018.

Menurut Situmorang et al., (2016), Estimasi Stok Karbon Tegakan menggunakan EVI dan indeks vegetasi NDVI di hutan produksi Kecamatan Lembah Seulawah, menyatakan jumlah stok karbon menggunakan EVI dengan luasan \pm 15.351 ha sekitar
$790.344,41$ ton atau nilai rata-rata stok karbon 51,48 ton/ha dan menggunakan NDVI adalah 711.061,81 ton atau nilai rata-rata stok karbon 46,32 ton/ha. Hal ini tidak jauh berbeda dengan jumlah potensi karbon berdasarkan kelas penutupan lahan Taman Hutan Raya Pocut Meurah Intan pada tahun 2018 dengan luasan \pm 6.215 ha sekitar 639.235 ton atau nilai ratarata stok karbon 41 ton/ha.

Potensi cadangan karbon berdasarkan kelas penutupan lahan yang dominan berada pada hutan lahan kering sekunder sebesar 575.523 ton (tahun 2003) dan semak belukar 74.431 ton (tahun 2015). Sementara potensi cadangan karbon terendah berada pada kelas lahan terbuka sebesar 16 ton (tahun 2003 dan 2006) dan pemukiman 167 ton (tahun 2015), serta hilangnya nilai potensi karbon pada kelas pertanian lahan kering (tahun 2018),

\section{Perubahan Penutupan Lahan Taman Hutan Raya Pocut Meurah Intan tahun 2003 - 2018}
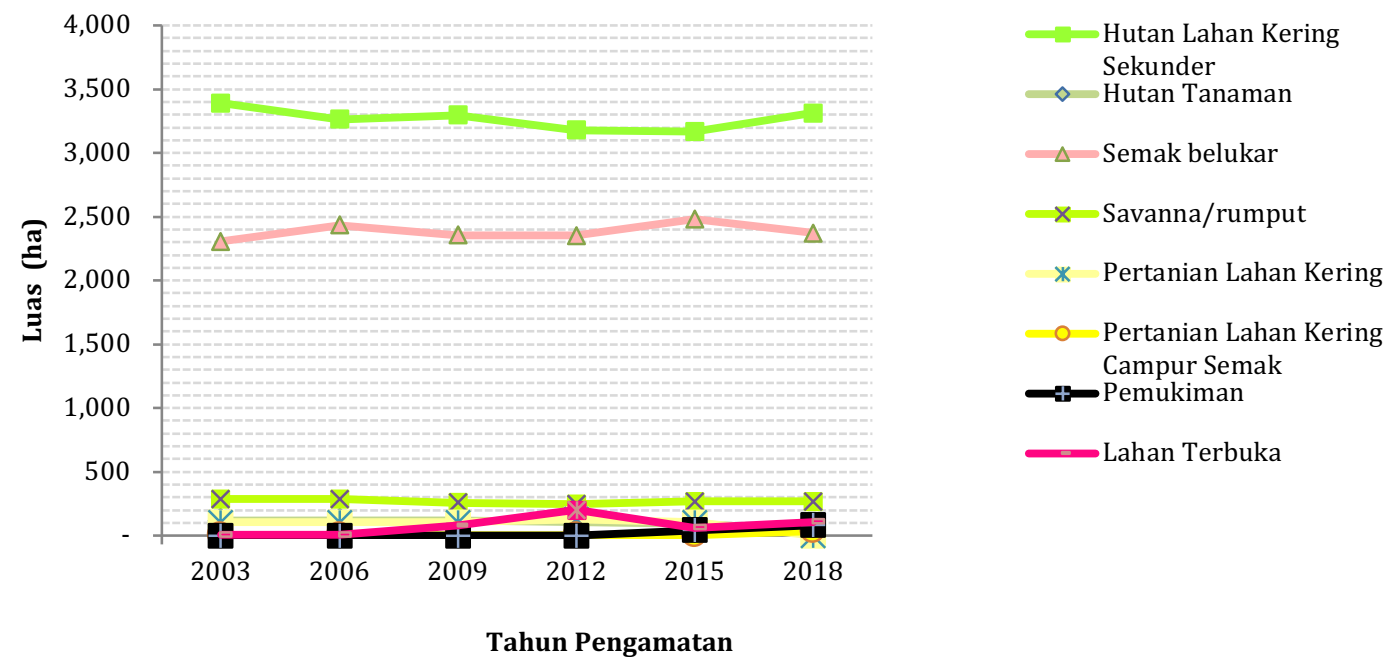

Gambar 4. Grafik perubahan penutupan lahan Tahura Pocut Meurah Intan tahun 2003-2018. (Sumber: Hasil pengolahan dan analisis data, 2020)

Tabel 4. Potensi cadangan karbon berdasarkan kelas penutupan lahan Taman Hutan Raya Pocut Meurah Intan

\begin{tabular}{llrrrrrrr}
\hline No & $\begin{array}{c}\text { Kelas Penutupan } \\
\text { Lahan }\end{array}$ & $\begin{array}{c}\text { Cadangan } \\
\text { karbon } \\
\text { (ton) }\end{array}$ & $\begin{array}{c}\text { Cadangan } \\
\text { karbon } \\
\text { (ton) }\end{array}$ & $\begin{array}{c}\text { Cadangan } \\
\text { karbon } \\
\text { (ton) }\end{array}$ & $\begin{array}{c}\text { Cadangan } \\
\text { karbon } \\
\text { (ton) }\end{array}$ & $\begin{array}{c}\text { Cadangan } \\
\text { karbon } \\
\text { (ton) }\end{array}$ & $\begin{array}{c}\text { Cadangan } \\
\text { karbon } \\
\text { (ton) }\end{array}$ & $\begin{array}{c}\text { Kandungan } \\
\text { karbon } \\
\text { berdasarkan } \\
\text { penutupan lahan } \\
\text { (C ton /ha) }\end{array}$ \\
\hline $\begin{array}{l}2 \\
1\end{array}$ & $\begin{array}{l}\text { Hutan lahan kering } \\
\text { sekunder }\end{array}$ & 575.523 & 553.825 & 559.529 & 539.404 & 537.574 & 562.138 & 169,70 \\
\hline 2 & Hutan tanaman & 9.045 & 9.045 & 9.045 & 8.166 & 7.104 & 3.233 & 76,70 \\
\hline 3 & Semak belukar & 69.207 & 73.020 & 70.659 & 70.582 & 74.431 & 71.158 & 30,00 \\
\hline 4 & Savanna/rumput & 1.148 & 1.148 & 1.036 & 986 & 1.067 & 1.064 & 4,00 \\
\hline 5 & Pertanian lahan kering & 1.030 & 1.030 & 1.030 & 1.267 & 1.023 & 0 & 10,00 \\
\hline 6 & $\begin{array}{l}\text { Pertanian lahan kering } \\
\text { campur semak }\end{array}$ & 83 & 83 & 83 & 83 & 83 & 1.049 & 30,00 \\
\hline 7 & Pemukiman & 0 & 0 & 0 & 0 & 167 & 324 & 4,00 \\
\hline 8 & Lahan terbuka & 16 & 16 & 201 & 504 & 151 & 267 & 2,50 \\
\hline & Jumlah Total & 656.053 & 638.167 & 641.582 & 620.992 & 621.600 & 639.235 & \\
\hline
\end{tabular}

Sumber : Hasil pengolahan dan analisis data (2020). Kandungan karbon setiap kelas penutupan lahan bersumber dari Direktorat IPSDH dan Badan Litbang Kehutanan Kementerian Kehutanan (Hasil Pengukuran NFI 1996-2013), 2014; Juknis PEP RAD GRK, $2013 ;$ Tosiani, 2015 dalam Buku Kegiatan Serapan dan Emisi Karbon Kementerian Lingkungan Hidup dan Kehutanan. 
Tabel 5. Matriks perbandingan emisi dan serapan karbon di Taman Hutan Raya pocut meurah intan periode tahun $2003-2018$

\begin{tabular}{|c|c|c|c|c|c|c|}
\hline \multirow{2}{*}{ No } & \multirow{2}{*}{$\begin{array}{l}\text { Kelas Penutupan } \\
\text { Lahan }\end{array}$} & \multicolumn{5}{|c|}{ Emisi dan serapan karbon (ton C02) } \\
\hline & & $2003-2006$ & $2006-2009$ & $2009-2012$ & $2012-2015$ & $2015-2018$ \\
\hline 1 & $\begin{array}{l}\text { Hutan lahan kering } \\
\text { sekunder }\end{array}$ & 79.559 & 20.912 & 73.790 & 6.711 & 90.071 \\
\hline 2 & Hutan Tanaman & 0 & 0 & 3.222 & 3.894 & 14.192 \\
\hline 3 & Semak belukar & 13.981 & 8.657 & 282 & 14.113 & 12.001 \\
\hline 4 & Savanna/rumput & 0 & 412 & 184 & 296 & 9 \\
\hline 5 & Pertanian Lahan Kering & 0 & 0 & 867 & 893 & 3.752 \\
\hline 6 & $\begin{array}{l}\text { Pertanian lahan kering } \\
\text { campur Semak }\end{array}$ & 0 & 0 & 0 & 0 & 3.543 \\
\hline 7 & Pemukiman & 0 & 0 & 0 & 612 & 578 \\
\hline 8 & Lahan Terbuka & 0 & 677,79 & 1.114 & 1.295 & 423 \\
\hline $\mathrm{Em}$ & & 79.559 & 9.069 & 77.478 & 12.793 & 29.954 \\
\hline Sel & apan & 13.981 & 21.590 & 1.981 & 15.021 & 94.615 \\
\hline
\end{tabular}

Potensi cadangan karbon pada tahun 2018 khususnya di kelas penutupan lahan hutan lahan kering sekunder mengalami penurunan, sementara kelas penutupan lahan lainnya mengalami kenaikan potensi karbon seperti pertanian lahan kering sekunder campur semak, pemukiman dan lahan terbuka. Tren perubahan nilai potensi karbon dapat mengindikasikan bahwa adanya peningkatan kebutuhan masyarakat dalam pembukaan lahan untuk bercocok tanam dalam kawasan Taman Hutan Raya Pocut Meurah Intan. Penghitungan perubahan cadangan karbon dilakukan dengan menggunakan analisa spasial data aktivitas dan data cadangan karbon/faktor emisi/faktor serapan untuk setiap kelas penutupan lahan Taman Hutan Raya Pocut Meurah Intan. Penghitungan serapan dan emisi karbon menggunakan data penutupan lahan Taman Hutan Raya Pocut Meurah Intan tahun 2003-2018 yang telah ditumpangsusunkan (overlay) periode per 3 tahun, yaitu tahun 2003-2006, 2006-2009, 2009-2012, 2012-2015, dan 2015-2018. Secara keseluruhan, laju serapan dan emisi karbon di Taman Hutan Raya Pocut Meurah Intan tahun 20032018 dapat dilihat pada Tabel 5.

Nilai serapan karbon yang memiliki serapan karbon terbesar pada tahun 2018 sejumlah 94.615 ton $\mathrm{CO}_{2}$ dan terendah pada tahun 20121.981 ton $\mathrm{CO}_{2}$. Berdasarkan kelas penutupan lahan, serapan karbon terbesar terdapat pada kelas hutan lahan kering sekunder tahun 2018 sebanyak 90.071 ton $\mathrm{CO}_{2}$, serapan karbon terendah berada pada kelas savanna/rumput pada tahun 2015 sebanyak 296 ton $\mathrm{CO}_{2}$.

Emisi karbon terbesar pada tahun 2006 sebanyak 79.559 ton $\mathrm{CO}_{2}$ dan terendah pada tahun 2009 sejumlah 9.069 ton $\mathrm{CO}_{2}$. Berdasarkan kelas penutupan lahan, emisi karbon tertinggi pada kelas hutan lahan kering sekunder tahun 2006 sebanyak 79.559 ton $\mathrm{CO}_{2}$, dan terendah pada kelas savanna/rumput tahun 20189 ton $\mathrm{CO}_{2}$. Argasetiawan et al.,(2018) melaporkan bahwa perubahan lahan tidak produktif pada pola ruang seperti lahan terbuka dan semak belukar menjadi hutan lahan kering sekunder memberikan 457 kontribusi paling besar untuk menurunkan emisi karbon. Penutupan/penggunaan lahan hutan memberikan dampak positif terhadap kemampuan dalam penyerapan karbon.

\section{Kesimpulan}

Selama kurun waktu 15 tahun dari tahun 20032018 (periode per 3 tahun) telah terjadi perubahan penutupan lahan Taman Hutan Raya Pocut Meurah Intan baik penambahan maupun penurunan luas. Perubahan luas penutupan lahan terbesar terjadi pada tahun 2018 seluas 263 ha dan terendah pada tahun 2009 seluas 108 ha. Selama kurun waktu 15 tahun dari tahun 2003-2018 diperoleh penurunan luas penutupan lahan kelas hutan lahan kering sekunder seluas 79 ha $(2,33 \%)$, hutan tanaman 76 ha (64\%), savanna/rumput 21 ha $(7,33 \%)$, kelas pertanian lahan kering menjadi hilang 103 ha $(100 \%)$. Sementara penambahan luas penutupan lahan terjadi di kelas semak belukar seluas 65 ha $(2,82 \%)$, pertanian lahan kering campur semak 32 ha $(116,2 \%)$, pemukiman 81 ha $(100 \%)$ dan lahan terbuka 100 ha $(158,5 \%)$. Perubahan luas penutupan lahan secara umum mengalami penurunan luas yang diakibatkan oleh meningkatnya pemanfaatan lahan untuk pemukiman dan perluasan lahan untuk pertanian lahan kering campur semak.

Potensi cadangan karbon berdasarkan kelas penutupan lahan kurun waktu 15 tahun dari tahun 2003-2018 mengalami tren penurunan, dimana potensi cadangan karbon tertinggi pada tahun 2003 sebesar 656.053 ton, terendah pada tahun 2012 sebesar 620.992 ton dan tahun pengamatan terakhir (tahun 2018) berjumlah 639.235 ton.

\section{DAFTAR PUSTAKA}

Akbar M, Sugianto, Hairul B. 2018. Analisis Penggunaan Lahan Eksisting Berdasarkan Rencana Tata Ruang di Kecamatan Lembah Seulawah Kabupaten Aceh Besar Jurnal Ilmiah Mahasiswa Pertanian. Volume 3, Nomor 2, Mei 2018. www.jim.unsyiah.ac.id/JFP. 
Arga S, Roland A, Daud M. 2018. Emisi Karbon Berbasis Penutupan Lahan dan Pola Ruang di Daerah Aliran Sungai Bonehau. Tesis. Universitas Hasanuddin.

BSN, 2010. Klasifikasi Penutup Lahan. Standar Nasional Indonesia. SNI 7645:2010. ICS 07.040. Badan Standardisasi Nasional.

BSN, 2014. Metode Penghitungan Perubahan Tutupan Hutan Berdasarkan Hasil Penafsiran Citra Penginderaan Jauh Optik Secara Visual. Standar Nasional Indonesia. SNI 8033:2014. ICS 65.020. Badan Standardisasi Nasional.

Brown, 1997. Estimating Biomass dan Biomass Change of Tropical Forest. A Primer. FAO Paper 134.

Djufri, 2003. Natural food monitoring of Sumatran elephant (Elephas maximus sumatraensis) in Taman Hutan Raya Cut Nya' Dhien Seulawah, Aceh Besar.[disertasi].

FAO, 2007a. Forest monitoring and assessment for climate change reporting: partnership, capacity building and delivery. Forest Resources Assessment. Working Papers. 142. Rome.

IPCC, 2006. Guidelines for National Greenhouse Gas Inventories - Volume 4 - Agriculture, Forestry and other Land Use. Institute for Global Environmental Strategies, Japan.

Ismed, R. Hairul B, Fauzi H. 2013. Pendugaan Cadangan Karbon Taman Hutan Raya Pocut Meurah Intan Provinsi Aceh. Jurnal Manajemen Sumberdaya Lahan. Volume 3, Nomor 1, April 2014: hal. 390-395.

Jensen, J. R., 2007. Remote Sensing of the Environment. Second Edition Pearson Prentice Hall.
Keputusan Menteri Kehutanan Nomor 95/Kpts-I/2001 tentang Penetapan Kawasan Hutan Tetap dengan Fungsi Hutan Taman Hutan Raya Cut Nyak Dhien.

KLH, 2012. Pedoman Penyelenggaraan Inventarisasi Gas Rumah Kaca Nasional: Buku II. Pedoman Umum, Volume 3, Metodologi Penghitungan Tingkat Emisi dan Penyerapan Gas Rumah Kaca, Pertanian, Kehutanan dan Penggunaan Lahan Lainnya. Kementerian Lingkungan Hidup. Jakarta. 163 hal.

Samsul Kamal, Elita Agustina, Azhari. Keanekaragaman Spesies Burung Pada Beberapa Tipe Habitat di Kawasan Taman Hutan Raya Pocut Meurah IntanProsiding Seminar Nasional Pendidikan Biologi (ISBN: 978-602-61265-2-8), Juni 2018.

Situmorang J.P, Sugianto, Darusman. 2016. Estimation of Carbon Stock Stands using EVI and NDVI vegetation index in production forest of lembah Seulawah subdistrict, Aceh Indonesia. Aceh Int. J. Sci. Technol., 5(3), 126-139 December 2016 ISSN: 2088-9860 doi: 10.13170/aijst.5.3.5836.

Tahura Pocut Meurah Intan. 2016. Dokumen Rencana Pengelolaan Jangka Panjang UPTD KPH Tahura Pocut Meurah Intan Provinsi Aceh Periode 20162025. Banda Aceh.

Tosiani, A. 2015. Buku Kegiatan Serapan dan Emisi Karbon. Kementerian Lingkungan Hidup dan Kehutanan, Direktorat Jenderal Planologi Kehutanan dan Tata Lingkungan, Direktorat Inventarisasi dan Pemantauan Sumberdaya Hutan. Jakarta. 55 hal. 